\title{
Commoning the Komal: The Toronto Kurdish Community Centre
}

\author{
Elif Genc ${ }^{1}$
}

\author{
New School for Social Research, New York, USA
}

\begin{abstract}
Within the walls of an unremarkable two-story storefront in a strip mall in suburban Toronto, a distinct alternative practice of radical politics and life is taking place. In fact, what would appear to be an extension of the Kurdish social movement, as it is understood, is being practiced against a backdrop of the refugee experience within the metropolitan city limits of Toronto. This practice of what is arguably feminist anarchism has identified itself in recent years by the title "Democratic Confederalism". Democratic Confederalism in its feminist anarchist framework reflects an understanding of what is known within the Marxist tradition as "the commons". This paper seeks to show that the Kurdish Community Centre has, over nearly three decades, evolved for its members within Toronto into a space that attempts to practice this radical feminist politics mirroring our understanding of "the commons". However, as with many leftist social movements, struggles with the glaring divide between theory and praxis across space and time mark the centre's main concerns. Limited by the diasporic experience, these Kurdish refugees are faced with trying to navigate their anti-state Kurdish revolutionary struggle within a nation that has provided them refuge. This paper will explore what is understood as "komal" (community) and how these community centres have come to represent the Kurdish social movement in diasporaric spaces through refugee lived experiencesparticularly that of the Kurdish woman's. Their radical feminist politics, which have been most prominently articulated in the movement through armed struggle against oppression in urban and rural spaces, can only be reflected in a Canadian setting by the TKCC working to form solidarity with various other oppressed groups who share similar politics -- a variety of third world, women-of-color feminism that is about critique and spaces of coalition building unlike that of second wave white feminists. Traditionally the movement's feminist project claims to be that of disidenfication. Contrasingly, in Canada where their identification as Kurds and as refugees is an organizing epistemology, pushing policy by lobbying the Canadian government becomes essential.
\end{abstract}

Keywords; Kurdish social movement, Democratic Confederalism, Diaspora, Canada

\section{Introduction}

In a smallish plaza in an undistinguished -- quite frankly unattractive--area of North York in Toronto, Canada, from the outside it appears to be one of the standard storefronts that change hands on a regular basis. A closer look reveals the sign "Toronto Kurdish Community Centre." Given the range of ethnic community centres across this multicultural city, this one is unlikely to catch the average pedestrian's eye (perhaps by design). As soon as you enter, however, passing beyond the heavy green curtains that cover the otherwise open storefront, you realize that there is something going on here beyond the predictable activities of a cultural community centre. This is not just about communityfocused language courses, folk-dancing, music and immigration services. Upon entry into the immense reception area, you are immediately struck by the painting of a panoramic mountain range with the images of what appear to be very striking, if not grandiose, political profiles of Kurdish figures. Eventually, you learn that these constitute the most revered political revolutionaries of the Kurdish movement: Kemal Pir and M. Hayri Durmuş, two political prisoners who died of hunger strikes in Diyarbikr prison in horrific conditions in the 1980s (Özcan, 2006). Overarching the mountain is the figure of Abdullah Öcalan - the present day leader and intellectual inspiration of the Kurdish revolutionary movement. The walls of the centre are decorated with pictures of şehids (martyrs) of the Kurdish struggle

\footnotetext{
${ }^{1}$ Correspondent e-mail: gence572@newschool.edu
} 
dating back to the fallen revolutionaries who died opposing the formation of Turkish Republic -- such as Seyid Riza, revolutionary leader of the infamous 1938 Dersim uprising (a movement whose entire membership was hung by the Turkish state) -- and extending up to contemporary exponents of the Kurdish struggle, like Robert Gallagher and Nazzarano Tossane, two Canadians who died fighting with the People's Protection Units (Yekîneyên Parastina Gel YPG). Emblazoned above the awning are the words: AN AZADÎI AN AZADÎ (to freedom, to freedom).

When you begin to explore the room, you find a wide assortment of mementos of the Kurdish struggle. In one corner is a bookshelf of literature written almost entirely by Öcalan, the dominant force in Kurdish intellectual life. Indeed, the second floor is a room entirely full of revolutionary literature in both Kurdish and Turkish. What is also striking is that the whole place is covered with red, green, and yellow (kesk $\hat{u}$ sor $\hat{u}$ zer) ribbons, paint, and a number of similarly coloured flags of different various Kurdish armed forces. The walls are lined with sofa benches and plush pillows; a few tables with chairs are set up along these seats in an arrangement which actually looks quite inviting. There is a kitchen in the back that almost always has a pot of tea brewing on the stovetop. Both the first and in a smaller version the second floors are large open spaces ideal for Kurdish folklore dancing, choirs, and language classes -- but more importantly for political assemblies. Thus despite its otherwise mundane appearance from the outside, the inside of the community center is the site of the assemblies and congresses of the revolutionary struggle that make the TKCC a space of radical --if fractured -- transformative politics.

Within these walls, then, a distinct alternative practice of radical politics and life is being undertaken. In fact, what would appear to be an extension of the Kurdish social movement, as it is understood, is being practiced against a backdrop of the refugee experience within the metropolitan city limits of Toronto. This practice of what identifies itself as feminist anarchism has in the recent years adopted the title "Democratic Confederalism" (Öcalan, 2011). Democratic Confederalism in its feminist anarchist framework reflects the understanding of what is known within the Marxist tradition today as "the commons" (Federici \& Linebaugh, 2018). This paper seeks to show that the Kurdish Community Centre has, over nearly three decades, established for its members within Toronto a space that attempts to practice a radical feminist politics mirroring our understanding of "the commons". However, similar to the dilemma of many leftist social movements, conflicts between theory and praxis across space and time mark the centre's main concerns. Within the limits of the diasporic experience within a nation that has provided them refuge, the Kurdish refugees are faced with trying to navigate their anti-state Kurdish revolutionary struggle.. This paper will explore what is understood as "komal" (community) and how these community centres have come to represent the Kurdish social movement in diasporic spaces through refugee lived experiences - particularly the Kurdish woman's. Their radical feminist politics, which have most prominently been articulated in the movement through armed struggle against oppression in urban and rural spaces, can only be reflected in a Canadian setting by the TKCC working to form solidarity with various other oppressed groups who share similar politics, a variety of third world, women-of-color feminism that is about critique and spaces of coalition building unlike that of second wave white feminists (Butler, 2002; Federici \& Linebaugh, 2018). Traditionally the movement's feminist project claims to be that of disidenfication. Contrastingly in Canada where their identification as Kurds and as refugees are organizing epistemologies, pushing policy by attempting to lobby the Canadian government becomes essential.

\section{Theoretical Considerations}

To date, there is no diaspora literature about the Kurdish communities in North America that carry on practices of democratic confederalism. What accounts for this lacuna are a number of factors -- the recency of the migration waves, the inaccessible spaces, language barriers, and the undocumented refugee experience -- collectively creating a barrier today between the community and the rest of Canadian or specifically Torontonean society. In addition, the language of democratic federalism is not part of the vocabulary or practice of political systems in Canada. For the time being, then this paper stands as the first tentative ethnographic critical analysis of the Kurdish diaspora community in Toronto. ${ }^{2}$

To better understand these processes, I situate these practices in relation to the existing literature on diasporic communities, specifically, on place-making (Fainstein \& DeFilippis, 2015; Friedmann, 2017; Raffles, 1999;) Placemaking is a political act that incorporates transnational contestations of identity and violence (Friedmann, 2017). In the space of the host nation, Kurdish diasporas enact these transnational politics and new social formations that challenge the very existence of the nation-state. Since women are at the centre of these practices, these acts raise important questions about gender, particularly in shifting politics away from the nation-state and towards localized

\footnotetext{
${ }^{2}$ I have been active in the TKCC for the last five years during which I have been in the International Relations Committee and since 2016 the Cochair Assistant of the newly formed Democratic Kurdish Federation of Canada, formally the International Relations Committee. Over this period of time I have observed and participated in many of events, memorials, and protests. At this point this ethnographic fieldwork is based purely on my observations and interviews conducted and is not to be considered exhaustive as it is in any way. All translations from Turkish and Kurdish are mine unless otherwise cited.
} 
feminist politics that challenge the way that space is occupied. The TKCC is a space that is transformed into a Kurdish place through a variety of acts of place-making. The TKCC is reflective of these contradictions because it is a nexus of these forces, a point of convergence of conflicts that are specific to its constituency - that of predominantly working class adherents of the Kurdistan movement of Abdullah Öcalan working towards anarcho-feminism.

This social experiment in radical democracy at the TKCC is the direct offspring of a decades-long historical feminist struggle of the Kurdish social movement against the Turkish state and patriarchy, stretching from an initially Marxist-Leninism/Stalinist affiliation to a recent one with Murray Bookchin's (1982) feminist anarchism (Keyder \& Üstündağ 2006; Mojab, 2003). Following the arrest of Abdullah Öcalan, the revolutionary leader of the movement imprisoned since 1999 off the coast of Istanbul on Imrali island, the movement went through a marked period of transformation from Leninist/Stalinist structuralism to Öcalan's democratic federalism, informed by his reading of Bookchin among many other leftist theorists and his prolific writing. His "democratic confederalism" ideology is essentially a blueprint for an ecological and sociological system based on egalitarian principles and bottom-up grass roots organization, echoing Bookchin's (1982) "libertarian municipalism".

Democratic confederalism in its theory and practice appears to mimic what we would understand as an experiment in feminist anticapitalist "commons" (Federici \& Linebaugh, 2018). These transformative social relations exist within what is known as the Kurdish womens' social movement. Silvia Federici (\& Linebaugh 2018), in her quest to understand the commons, claims that it must exhibit collective reappropriation and struggle. Generally the commons exhibits four main characteristics: 1) all wealth should be shared, 2) commons requires obligation as well as entitlement, 3) commons of care are also communities of resistance that oppose all social hierarchies, and 4) commons are the 'other' of the state form. Federici (\& Linebaugh 2018) also insists that the "politics of the commons" must be conducted from within the feminist subaltern tradition. In her project, she refers to this feminism as the struggle against sexual discrimination and social reproductive work. The concept of 'social reproduction' has been used by feminist political economists to refer to the combination of activities, mainly performed by women in the household, necessary for the daily and intergenerational maintenance of the working population and the overall preservation of the capitalist mode of production (Laslett \& Brenner, 1989; Luxton \& Bezanson, 2006; Picchio, 1992). Federeci (\& Linebaugh 2018) argues that: "As a woman and a feminist, she observes the production of the commons in the everyday labors of reproduction - the washing, cuddling, cooking, consoling, sweeping, pleasing, cleaning, exciting, mopping, reassuring, dusting, dressing, feeding children, having children, and caring for the sick and the elderly" (Federici \& Linebaugh, 2018).

Similar to the commons, the Kurdish social movement in praxis emulates collective decision-making through assemblies and other forms of radical democracy. Decision-making in the commons must be a bottom-up, grassroots process (Federici \& Linebaugh, 2018). In practice, this results in the united political phenomenon of the co-chair principle, gendered armed civil protection units and autonomous grassroots neighbourhoods and municipalities attempting to create varied practices of Öcalan's democratic confederalism (Üstündağ, 2016). Its most fully realized form to date is what has become known as the cultural revolution of Rojava -- its recent official title: Democratic Federation of Northern Syria ${ }^{3}$. Rojava claims to have overcome the reproduction of statist patriarchal relations altogether (Knapp \& Jongerden, 2014; Öcalan, 2011; Üstündağ, 2016). Inspired by these principles, the Rojava cantons enforce co-presidencies and quotas, and create women's defense units, women's communes, academies, tribunals, and cooperatives in the midst of war and under the weight of an embargo. The women's movement is autonomously organized in all walks of life, from defense to economy to education to health. Autonomous women's councils exist parallel to the people's councils and can veto the latter's decisions. Men committing violence against women are not allowed to be part of the administration. Gender-based discrimination, forced marriages, domestic violence, honour killings, polygamy, child marriage, and dowry are criminalized (Knapp \& Jongerden, 2014). Many non-Kurdish women, especially Arabs and Assyrians, join the armed ranks and administration in Rojava and are encouraged to organize autonomously as well. In all spheres, including the internal security forces (Asayîş) and the YPG and the People's Women's Defence Units (Yekîneyên Parastina Jin YPJ), gender equality is a central part of education and training. For example, Cizire canton representatives are currently a Kurdish woman and an Arab tribal leader, thereby taking into account other societal issues and differences as they organize. These all were made possible by a power vacuum created in the region vacated by the Assad regime, transforming the space into a war economy when ISIS with their patriarchy-driven forms of violence of enslavement and rape invaded Rojava in 2015 (Dirik, 2015; Genç, 2017; Üstündă̆, 2016)

We see similar examples of feminist and socialist continuities from the Kurdish regions of Turkey in the main urban centres in the form of autonomous municipalities. Recently, in 2015 to 2016, these latter autonomous

3 As of September 2018, Autonomous Administration of North and East Syria (NES) (The Independent, Caroline Mortimer, Sunday 4 February 2018). 
neighbourhoods -- in Bakur, in the cities of Cizre, Nusaybin, Sirnak, and Sur in Diyarbakir -- were consistently and brutally crushed by the Turkish state so that very little remains of them today ${ }^{4}$. However, their tradition and practice of radical feminist anarchism can still be found across Europe and most recently in Australia, Japan and, as this paper attests, in Canada.

According to its mandate the TKCC is obligated:

To protect and develop further the social, economic, political and cultural rights of the Kurdish people. Our community adopts the principles of international law and strongly supports the laws aimed at preventing discriminations based on race, gender, religion, language and culture. Guided by the above principles the mission of Toronto Kurdish Community is to alleviate problems of the Kurdish society resulting from migration as well as to promote and inform the Canadian public and institutions about the struggle of the Kurdish people for their existence, language, culture and national identity ${ }^{5}$.

As much as these elements inform the space, there is a also a transformative form of politics taking place qualifying it as a commons. The model for the space traces from what is known as the "komal." Komal means community in Kurdish. Originating from the birthplace of the Kurdish women's social movement in Turkey, these centres are used mainly as organizing spaces to conduct the affairs of the Kurdish social movement and practice radical feminist politics in urban spaces. Unfortunately within Turkey, the level of oppression that the Kurdish people have faced since the establishment of the Turkish republic does not lend itself to these komals lasting very long. They are generally historically and currently shut down by the Turkish security forces across the country and their members are arrested. Over the decades of colonial oppression, the large-scale displacement of the Kurdish population in Turkey has led to a mass exodus of Kurdish refugees to Europe - numbering in the hundreds of thousands. Consequently, unlike in Turkey, within European countries (mainly Germany, Belgium, France, and England), these Kurdish political asylum seekers were able to practice for the first time freely and engage with their social movement and voice their struggle, so that, across Europe, there are countless komals where the tradition lives on. With European Kurds becoming more and more established, and simultaneously more integrated into the local culture, there has been an increasing amount of diaspora literature reflecting their continued revolutionary struggle (Eccarius-Kelly, 2002; Ostergaard-Nielsen, 2000; Wahlbeck, 1998)

The TKCC in Toronto is where some 2000 Kurdish people congregate, of the estimated 10,000-12,000 Kurdish people from Turkey in Toronto, nearly all of them coming as refugees. These figures are inexact owing to the lack of documentation on the Kurdish population from Turkey, since their national identity is unrecognized by Canada's census. Kurds are a fairly new migrant group to Toronto. This differs from the movement of Kurds to the USA composed of those who came as refugees in the late 1970s to Nashville, Tennessee (as Stanley Thangaraj, Aynur de Rouen, and Demet Arpacik address in this special issue). Unlike the large Kurdish population in Nashville who come from South Kurdistan (Iraqi Kurds), the Kurds arriving in Canada are fleeing genocidal violence in Turkey. The first wave of these Kurdish refugees arrived during the late 1990s/early 2000s following the Maraş massacre of 1978 (McDowall, 2003). The slaughter of hundreds of Alevi Kurds by Turkish nationalists and religious zealots in the city of Kahramanmaraş produced a wave of thousands of refugees. This wave arriving in Toronto consisted mostly of Alevi Kurds escaping both religious and political persecution. The second and ongoing wave are Kurds from the other side of Kurdistan, from villages in Ağri province. They usually come as socio-economic asylum seekers as well as for political refuge. In all of these waves, people came with or eventually brought over their extended families which accounts for the substantial numbers in so few years. Currently, as the situation in Turkey deteriorates due to the recent years of increased conflict and oppression of the Kurdish people following the "trench wars", this number continues to rise significantly; the remainder of the population is from a wide swathe of cities ranging from Diyarbakir, Bingol, and Elbistan (Genç, 2017). The community centre itself was founded in 1992 and has moved several times: from downtown Toronto, to midtown, to currently north of the city -- in each case, due to the proximity of the community. Now that the community is increasingly moving to the suburbs of Toronto, there is much talk and debate about moving the centre even further north. The pattern of the community centre changing location in relation to where the community lives implies that the members of the community as a whole orient their lives around it.

\footnotetext{
${ }^{4}$ The 79-day Siege of Cizre, announced on the 14th of December, 2015, is a report that consists of interiews, accounts and observation that the HDP Cizre Working Committee undertook between March 3-12, 2016.

${ }^{5}$ For further description see the link of the TKCC website: http://www.kurdishcc.com/\#!portfolio/cngp
} 
One of the more striking aspects of the TKCC is that there are nearly daily commemorative events of the tragic history of the Kurdish struggle and also its martyrs (şehids). While every funeral is to some degree a "celebration of life", within the Kurdish social movement death and life are aligned to an exceptional degree; as Hişyar Özsoy (2010) argues "The Kurds resurrect their dead as martyrs - affective forces that powerfully shape public, political and daily life and promote Kurdish national identity as a sacred communion of the dead and the living" (Özsoy, 2010). Funeral ceremonies (cenaza) have become spaces of transformative radical politics. This practice arose as a result of the uprising (serhildan) in the early 1990s, first in Kerboran (Dargeçit) and Nusaybin districts of Mardin and Cizre district of Şırnak after the funerals of the Kurdish Workers' Party (Partiya Karkerên Kurdistan PKK) guerrillas (Özsoy, 2010). Since the early 1990s the reclaiming of death through rituals of martyrdom can include: ululations and decoration of the coffin with red-yellow-green (colours of Kurdish movement) pennants as well as dancing govend (folk dancing) to resistance and singing prohibited Kurdish songs.

Similarly on a transnational scale, the Centre actively worked with the YPG to repatriate two Canadian martyrs who were killed in Rojava: John Robert Gallagher (named in Kurdish Gabar Rojava) and Nazzarono Tassone (Agir Ararat). ${ }^{6}$ In fact, members were assigned by the YPG to give the news to the families of the death of their sons which is customary of the Kurdish movement to do for families of fallen guerrillas. ${ }^{7}$ In both cases the centre received the funeral caskets with celebration and adorned them with the colours of the Kurdish movement (red, yellow, and green) and Rojava flags, participating in a funeral procession on the "Highway of Heros" to both of their respective places of birth. ${ }^{8}$ Both of these martyrs' pictures hang on the wall of the TKCC and the community over the years has made an effort to consistently visit and maintain relations with the families - similar to what the movement would have done back home.

This practice of martyrdom translates within diaspora spaces as the memorializing of the fallen guerrillas as well, which involves coming together in an arranged space on the anniversary of their death to honour that particular martyr of the Kurdish movement. Since as far back as people can remember, the TKCC has organized, and its members attended, many memorials of fallen martyrs such as Sakine Cansiz, Fidan Doğan, and Leyla Şöylemez -- all massacred in Paris. ${ }^{9}$ There are often pictures, symbols, videos, candles -- anything portraying that martyr. Such memorials are generally more sombre events in comparison to the funerals. Also before any event related to the Kurdish women's movement, there is always a moment of silence for the fallen martyrs. One of the most popular sayings of the movement during funerals and memorials is şehid namirin (martyrs never die), an expression of the martyrs' immortality.

A considerable amount of the centre's labour is directed towards protests and rallies in the streets of Toronto which involve preparation at the centre. Usually following the direction of its European counterparts, the TKCC members and friends will occupy the streets of downtown Toronto and block off Yonge Street (the longest street in Toronto) or in some cases congregate in Dundas square ${ }^{10}$. In their limited English, they will chant slogans, or in Kurdish -- such as Berxwedan Jîyane (Revolution is life) and Jin, Jîyan, Azadî (Women, life and freedom). Women, men and children wave flags, sing revolutionary songs, dance and give interviews and supply press releases. The reason for these events can range from a violation against the Kurdish people in any of the four regions, (generally by Turkey but can include other countries) to a celebration of particular expressions of revolution and resistance in the movement -of which there are plenty. On rare occasions, these protests will result in a trip to the Parliament buildings in Ottawa where assigned delegates on behalf of the community will try to meet with Members of Parliament to lobby their cases while the community is outside protesting and bringing awareness to the Canadian people. All of this echoes the uprising (serhildan) tradition in the Kurdish regions of Turkey - clearly on a much smaller scale and not facing the same state oppression which is precisely why these events can reach impressive numbers, hundreds of thousands in Europe, and hundreds in Toronto.

The TKCC also participates in reclaimed international revolutionary days of celebration, similar to what they would do back home. These include the International Workers Day of May $1^{\text {st }}$ and the International Working Women's Day on March $8^{\text {th }}$. In both cases the community adorned with their flags, colours, and slogans will participate in some of the larger marches organized by leftist groups in Toronto. In fact in the case of International Women's Day in

\footnotetext{
${ }^{6}$ For more information on Robert Gallagher: https://news.vice.com/en_us/article/mbn33q/john-gallagher-died-fighting-the-islamic-state-his-storyis-more-than-tragedy; For more information on Nazzarono Tassone: https://www.cbc.ca/news/canada/hamilton/nazzareno-tassone-1.4171349

${ }^{7}$ I was one of the community members who delivered a letter from the YPG in person to Nazzarono Tassone's family in Niagara Falls, Canada in January 2017

${ }^{8}$ For more information: http://embed.scribblelive.com/Embed/v7.aspx?Id=1659282\&Page=1\&overlay=false

9 "The Martyrs of Paris and Silopt commemorated in Toronto, ANF January 15, 2019 https://anfenglish.com/women/the-martyrs-of-paris-and$\underline{\text { silopi-commemorated-in-toronto-32139 }}$

${ }^{10}$ For more informaton see Kurdish-Canadians protest attack by Turkey on CP24.com Dec. $17^{\text {th }}, 2017$ https://www.cp24.com/video?clipId=698098
} 
Toronto, the Kurdish Women's Congress of the TKCC has recently become a main participant and organizer of the event held annually. They even go so far as to throw a gala event for IWWD, which the woman's congress is responsible for hosting. Ironically, men are not only invited but come close to dominating in numbers. In the past they have held events in the centre for Palestinian solidarity work and have been invited and visited First Nations leaders at reserves in Canada. These examples are impressive evidence of the degree to which the TKCC tries to create solidarity networks with other leftist and feminist organizations in the city, again following direction from their European predecessors.

Aside from this, the community hosts two huge revolutionary events that are open to the public and in the past attract numbers in the thousands. One is Newroz (New Year's) on March $21^{\text {st }}$ and the other is the annual Kurdish festival that coincides with the anniversary of the inception of the Kurdish movement-August $15^{\text {th }}$. For months, all the centre's efforts are focused on the preparation for these two events. Newroz, the Kurdish New Year, holds a specific historical and revolutionary significance for the Kurdish cause. ${ }^{11}$ On Newroz of 1982, Mazlum Doğan, one of the founding members of the PKK, while imprisoned, set his cell on fire and hanged himself. This desperate act of selfimmolation was his last resort against the horrific conditions of the Diyarbakir prison (Orhan 2016). Every Newroz, Mazlum Doğan is resurrected as a martyr as a central part of the celebration particularly outside of Turkey where his image is not prohibited. Today the fact that the celebration of Newroz is still banned in Turkey, and this year was even banned in the recently annexed canton of Afrin (Êfrin) in Rojava, makes it that much more critical to the movement to celebrate in the face of Turkish state oppression. Every year, millions of people flock to Diyarbakir (Amed) in the Kurdish part of Turkey to celebrate Newroz in spite of the Turkish state crackdown. Even though Newroz is usually celebrated outside, the TKCC will reserve a banquet hall and adorn it with pictures of Öcalan, martyrs, flags, colours, and in some cases interestingly enough, the Canadian flag. Often Canadian MPs (of whichever party happens to be supporting the Kurdish cause at that moment) will be invited to speak at the event, regardless of their overall political platform -- even should that be in opposition to the tenets of the Kurdish movement. The Canadian flag, alongside Öcalan's images and the presence of Canadian MPs epitomizes the degree to which the Kurdish community reconciles itself with the paradoxes that they experience as refugees seeking asylum in Canada while maintaining their revolutionary aspirations.

The women, as is customary, will wear traditional Kurdish dresses called fistan and the men dress in guerrilla style with customary salwar. Even the children will be dressed from head to toe in beautiful embroidered traditional clothes. The adornment of traditional dress is one of the key aspects of the revolutionary expression of Newroz, since typically Kurds were forbidden from wearing them by the Turkish state. Today they have become one of the symbols of the Kurdish social movement, particularly the women's dresses which are also worn in celebration of March $8^{\text {th }}$ IWWD. The night will be filled with traditional dances involving all members of the community -- women, youth, children etc. -- and will feature famous international Kurdish singers who sing prohibited and revolutionary songs all night. Most importantly there will be govend (halay) circle dance which has become one of the most expressive forms of articulating the Kurdish movement. It should be mentioned that govend is also danced at protests, hunger strikes, and pretty much every event of the movement except for memorials. This revolutionary tradition of dance exists across the board from the mountains of Kurdistan to urban Toronto. The Kurdish Cultural festival in the summer is very similar to Newroz in all the above respects except it takes place outside.

However nothing exemplifies more the experience of the commons at the TKCC then when there are hunger strikes going on in the movement. This is when the extent to which the TKCC has the potential to be a radical commons comes to light. Hunger striking as a form of resistance has a long and tortured history within the Kurdish movement, dating back to the Diyarbakir prison of 1980s (Bargu, 2014; Özcan, 2006). Typically occurring in prisons, the hunger strike has become one of the last resorts of the Kurdish movement to resist state oppression ${ }^{12}$. The most recent and widespread hunger strike, which just ended a few months ago, was in support of Leyla Güven, a Kurdish member of Parliament from the People's Democratic Party (HDP) in Turkey, who had been on an indefinite and non-alternate

\footnotetext{
11 the revival of the Newroz celebration has become more intense and politicized and has also become a symbol of the Kurdish revolution. By the end of the 1980s, Newroz was mainly associated with the attempts to express and resurrect the Kurdish identity. In 2000, Turkey legalized the celebration of the spring holiday, spelling it Nevruz and claiming it as a Turkish spring holiday. Also, using the Kurdish spelling Newroz rather than Nevruz, has been officially forbidden, though it is still widely used by Kurds. In the Kurdish regions of the country, specifically in Eastern Anatolia, but also in Istanbul and Ankara where there is a large Kurdish population, people gather and jump over bonfires. According to Human Rights Watch, the Kurds have had to struggle to celebrate Newroz, and in the past the celebration has led to violent oppression, leading to several deaths and mass arrests. (McDowall, 2003)

12 It is often argued that the notorious Diyarbakır Penitentiary, in which the inmates endured inhumane treatment and grotesque forms of torture, contributed to the substantial rise in the number of Kurds joining the ranks of the PKK, or, as popularly expressed, "taking to the mountains." Some inmates of Diyarbakır Penitentiary died as a result of torture or committed suicide, and some "took to the mountains" upon release. The cruel and inhumane treatment of the Kurdish activists during the military regime had undoubtedly radicalized them. It is only quite recently that the dark story of the Diyarbakır Penitentiary has been told via the memoirs of the surviving inmates (Kadığlu in Kastoryano (eds) 2013)
} 
hunger strike since November 8, 2018 of last year. Thousands across Turkey and Europe in the movement joined her to demand the end of the years-long isolation imposed on the imprisoned leader of the Kurdish women's social movement--Abdullah Öcalan. Many in the movement and outside it are of the belief that restarting peace talks with Öcalan presents the only solution to the ongoing conflict in the Kurdish regions of Turkey. This current hunger strike was similar to a previous one in late 2012 until 2013, which helped jumpstart the peace talks between the Turkish state and Öcalan to begin with. By the end of it, their hunger strike had entered into a critical stage and the health conditions of the strikers was rapidly deteriorating. ${ }^{13}$ There has been only one hunger striker in Canada: Yusuf Iba, a 28-year-old Kurdish journalist, started an indefinite and non-alternate hunger strike on January 13, 2019, in the Centre. ${ }^{14}$ Following his declaration to join the hunger strike, the community immediately responded, with many joining him on alternating and rotating hunger strikes throughout each night following his decision. Men, women and children participated and came to support Yusuf through this challenging and courageous process. The centre was open $24 \mathrm{hrs} / 7$ days a week, where at anytime one could find members of the community coming together in support by singing dengbej (traditional style of Kurdish music), dancing govend, and just passing hours visiting with Yusuf. In fact at one point, the elderly women of the community, held in high esteem as healers, came to give their good spirits and loving, motherly support to Yusuf during his tougher days. ${ }^{15}$ Even when Yusuf moved out of the TKCC into a fellow members' house, the community continued visiting him with their entire families. In fact the community lobbied to have Canadian MPs come and visit Yusuf and succeeded in having sympathetic MPs bring the ongoing issue to the House of Commons, ${ }^{16}$ This outpouring of community support is not exclusive to this past hunger strike. This is the regular protocol for the TKCC when anyone is on hunger strike; just previous to this episode, a group of men and women were on hunger strike for about a week at the centre and the community supported them in solidarity in precisely the same way. This period of the komal coming together in solidarity for hunger strikes is exemplary of a practice of commons going on in the everyday lives of the Kurdish people of Toronto. All of the above embody in some form or another what we would understand as "commons" existing within a community across space and time.

The KCK (The Kurdistan Communities Union -- Koma Civakên Kurdistan) is a Kurdish political organization that serves as an umbrella group for all the political parties that subscribe to democratic confederalism including its transnational counterparts. The transnational membership of the Kurdish political movement in the urban centre of Toronto is represented within the walls of the TKCC. In recent years, the TKCC has adopted the same set of radical principles of the Kurdish social movement regarding organization and has implemented congresses and councils in its political structure. Similar to its counterparts in Europe, the TKCC has now conducted three consecutive annual congresses which are divided into a number of commissions including: arts/culture, education, membership, international relations, finance, youth, and a variety of other issues. The congress is voted in by majority rule of the membership. There can be anywhere ranging from half of to just shy of a hundred in the main congress and a separate Women's congress which all women in the congress are obligated to be part of due to a lack of numbers and its centrality to the movement.

Nearly all of the members of the TKCC are working-class refugees. The majority of them are uneducated beyond high school (in some cases not even) and struggle with learning English while trying to adapt to the Canadian lifestyle. For the men of the community, the majority of them enter the construction sector where they work from dawn till dusk at sites all across the city, leaving them very little time in the evenings to attend the community centre's various events. Besides construction, they tend to be working in the restaurant industry, some eventually becoming owners. Otherwise they tend recently to be increasingly Uber/Lyft drivers, participating in the burgeoning sharing economy of Toronto. Somehow they navigate all these trials while living precariously during an arduous process of asylum review. Most of them are accepted for political asylum, having gone through extreme trauma from war and state oppression. In many cases, these Kurdish men are supporting or working to bring their (extended) families to join them in Canada. This puts on their shoulders a substantial financial burden that in some cases is alleviated by minimal government support; otherwise the onus is singly on them to provide for the family. The women, more often than not, are the social reproducers tending to the children and the house. Those who are single tend more often to go to school to learn English and pursue some sort of lucrative work. Needless to say, this quintessential patriarchal social

\footnotetext{
13 JIN TV Published on 1 Feb 2019 Tarihte Aclik Grevleri II (The History of Hunger Strikes II)

${ }^{14}$ I witnessed in the Centre the beginning of his strike firsthand and when I returned to NYC followed the developments closely until the end

15 ANF Toronto 7 February 2019 “ Kurdish hunger striker in Toronto visited by mothers" https://anfenglish.com/news/kurdish-hunger-striker-intoronto-visited-by-mothers-32738

16 ANF Toronto 1 March 2019 "Canadian MP visits Hunger Strikers Iba in Toronto" https://anfenglish.com/news/canadian-mp-visited-hungerstriker-iba-in-toronto-33273
} 
reproduction lifestyle does not lend itself well to pursuing feminist revolutionary politics at the community centre. This dynamic is also apparent with the low numbers of women of the TKCC; many of the men will choose to leave their wives at home to take care of their children while they attend the meetings and assemblies of the komal.

This has resulted in a situation, perhaps unique to Toronto, where the TKCC has become dominated by Kurdish men who claim to be practicing revolutionary feminist politics. The irony is not lost on anyone; during a congress, one of the senior female members reprimanded the men at the assembly for leaving their wives at home, declaring that she would rather see the women than the men. The situation is dire within the community, with the few women who are part of the Womens' congress struggling to increase their numbers and with a few individual women taking on the burden of all the feminist solidarity work. Yet despite all these obstacles, and a language barrier, the women's congress has surpassed all expectations with their recent work on IWWD and also in creating networks with international feminists that include the Filipino, Latin American and First Nations communities.

Sadly this issue with ongoing patriarchy is not exclusive to the Toronto community. Unfortunately this is a dynamic that is widespread across the Kurdish movement and its urban and rural spaces. There is apparently a popular saying in Kurdish (this was in relation to the municipalities in Diyarbakir) attributed to a female Kurdish member :

Kurdish movement [democratic confederalism] only exists until the door; once the men take off their shoes, democratic confederalism stays there with the shoes and then traditional roles are resumed by men and women. I know many examples where the men wax lyrical about the movement and the importance of women but privately they are extremely jealous and oppressive towards their partners. Like I said, many things have changed in Diyabakir but many things haven't changed.

This implies that the Kurdish movement defaults to patriarchy and social reproduction relations in the home and private sector. However from Toronto to Diyarbakir, significant lengths are being taken to change this dynamic in the movement itself. The same member said of the municipalities:

Of course we still have far to go but as far as I know, I think that this movement is extremely important for women. Many things have changed though together with this movement. The women have become much more political and much more involved in the movement without any prevention from their fathers and brothers and in fact encouragement which didn't use to be the case. In fact women in general have started to feel a certain security from the movement in general. For example you are held accountable to the neighbourhood councils to the municipal government where if you beat your wife or similar physical and psychological abuse, I know that they will cut the man's wage and give it to the woman. Officials will come to the door and conduct an investigation. Women live with the confidence that they can always go to the Kurdish women's movement and be protected by it against patriarchy. In fact the men have actually started to become afraid of the Kurdish women's movement, should there be any complaints against them etc. This is extremely significant.

This insight from the Kurdish women of the community centre, who have and continue to have these lived experiences, demonstrates the degree to which a feminist commons is an ongoing radical social experiment at the Toronto Kurdish Community Centre.

In contrast, the Kurdish communities within the United States, in small pockets across the Eastern and Western coasts (New Jersey, New England, Chicago, District of Washington and Bay Area in California), while also subscribing to democratic confederalism, seem to not be able to organize as efficiently and effectively as the Kurdish community of Toronto. A lot of factors could account for this, beginning with some hard numbersv-- data which is unavailable to and thus beyond the scope of this journal article but which leave us with some critical questions for consideration. Numbers alone cannot account for this estrangement and lack of cohesion within the Kurdish communities of the United States that are sympathetic to the Kurdish cause. Indeed recently there has been evidence of mass community organizing of those in Australia and Japan. What is distinctive to the community in the United States, differentiating it from all other komals in the world? The tradition seems to have been able, despite ongoing difficulties and contradictions, to flourish in Toronto. And though there have been many attempts at organizing, such as the American Kurdish Association (AKA) based in New Jersey, the New England Kurdish Association (NEKA) and the Kurdish Community Center of Chicago, none of these associations to date has been 
able to maintain an active membership of the Kurdish communities in those regions. ${ }^{17}$ What is distinctive about the Kurdish community centre of Toronto is that there is a space - a place-making -- that has allowed for the practice of for the komal to manifest itself in this Canadian urban setting. American individualism and neo-liberalism present themselves as prime suspects in preventing a commons similar to in Canada, specifically in Toronto, from evolving, but remain speculative. But significantly -- and ironically -- the precise factor that restricts the Toronto Kurdish community from taking on a revolutionary struggle of a kind traditional in Kurdistan (Bakur and Rojava) is the diplomacy that is at the centre of the relations the movement has with Washington DC. It is in the US that the majority of Kurdish pundits and intellectuals reside, and these use Washington's influence over the entire population of the Kurds in America to push policy with American senators who show support for the cause through diplomatic and strategic means.

In May of 2017, a watershed event took place in which an array of supporters of the Kurdish movement were attacked and beaten up by Erdogan's security forces -- an event that has become known as "Sheridan Circle" after its location in Washington DC, across the street from the Turkish embassy. ${ }^{18}$ This episode prompted an outpouring of support and outrage against the Turkish government by mostly Republican senators and ongoing criminal and civil litigation. Indeed it is Washington that is the battleground the Kurdish movement has to negotiate, through all the American government red tape and bureaucracy that is involved -- one leaving very little room for any sort of revolutionary aspirations. By contrast, the TKCC, though its members participate in many forms of government lobbying, cannot exert nearly the degree of pressure nor have nearly the degree of influence that pushing policy in Washington would have -- albeit ironically more able to maintain a coherent community structure. Similar to the issues of any idealistic commons, paradoxes arising between theory and praxis are magnified tenfold when involving refugees in the diaspora community trying to practice feminist radical politics -- and challenging its ability to meet Federici's criteria for a commons. Clearly there is a protracted struggle between overcoming the trauma of the refugee experience and their commitment to the Kurdish cause. Against this backdrop of feminist revolutionary aspirations, the members of the TKCC navigate the contradictions that are inevitable being a migrant population in a metropolitan capitalist city.

\section{References}

ANF Toronto. (2019, March 1). Canadian MP visits hunger strikers Iba in Toronto. Retrieved from https://anfenglish.com/news/canadian-mp-visited-hunger-striker-iba-in-toronto-33273

ANF Toronto. (2019, January 15) The Martyrs of Paris and Silopt commemorated in Toronto. Retrieved from https://anfenglish.com/women/the-martyrs-of-paris-and-silopi-commemorated-in-toronto-32139

ANF Toronto. (2019, February 7). Kurdish hunger striker in Toronto visited by mothers Retrieved from https://anfenglish.com/news/kurdish-hunger-striker-in-toronto-visited-by-mothers-32738

Bargu, B. (2014). Starve and immolate: The politics of human weapons. Columbia University Press.

Bookchin, M. (1982). The ecology of freedom: The rise and dissolution of hierarchy. PaloAlto, CA: Cheshire Books.

Butler, J. (2002). Gender trouble. Routledge.

Dirik, D. (Ed). (2015). Feminism and the Kurdish Freedom Movement. Proceedings from Dissecting Capitalist Modernity-Building Democratic Confederalism Conference (2015, April 3-5). Hamburg University.

Eccarius-Kelly, V. (2002). Political movements and leverage points: Kurdish activism in the European diaspora. Journal of Muslim Minority Affairs, 22(1), 91-118.

Fainstein, S. S., \& DeFilippis, J. (Eds.). (2015). Readings in planning theory. John Wiley \& Sons.

Federici, S., \& Linebaugh, P. (2018). Re-enchanting the world: Feminism and the politics of the commons. PM Press.

Friedmann, J. (2017). Place-making as project? Habitus and migration in transnational cities. In Habitus: A sense of place (pp. 331-349). Routledge.

Genç, E. (2017, November). Gender, State and resistance: The Kurdish women's armed struggle for liberation. Paper presented at the Middle Eastern Studies Association Conference (MESA), Washington, DC.

\footnotetext{
17 I have been organizing and active in the Kurdish community in both Canada and America simultaneously over the last five years. My friends and I formed a group in NYC briefly called HDK NYC (Peoples' Democratic Congress NYC); I've also have been an active member of AKA since 2016. I have participated in the events and interviewed many members (off the record) of both AKA, NEKA, and most recently the Chicago Kurdish community.

18 In May 2017, in a case still in the American courts, I was involved in what has become known as "Sheridan Circle" where my friends and I (mostly women, children and elderly gentlemen) were brutally attacked by Erdogan's security forces in front of the Turkish embassy in Washington DC during Erdogan's visit to DC.
} 
JIN TV. (2019, February) Tarihte Aclik Grevleri II (The History of Hunger Strikes II). Retrieved from https://www.youtube.com/watch?time_continue $=49 \& \mathrm{v}=$ Qr31eDLzIpg

Kadioğlu, A. G. (2013). "Necessity and state of exception: The Turkish State's permanent war with its Kurdish citizens," In R. Kastoryano (Ed.), Turkey between nationalism and globalization (142-161). London: Routledge.

Keyder, Ç., \& Üstündağ, N. (2006). Doğu ve Güneydoğu Anadolu'nun Kalkınmasında Sosyal Politikalar. Doğu ve Güney Doğu Anadolu'da Sosyal ve Ekonomik Öncelikler içinde (ed. Ethem Yenigün), UNDP-Açık Toplum Enstitüsü, TESEV Araştırması, 90-152.

Knapp, M., \& Jongerden, J. (2014). Communal democracy: The social contract and confederalism in Rojava. Comparative Islamic Studies, 10(1).

Laslett, B., \& Brenner, J. (1989). Gender and social reproduction: Historical perspectives. Annual Review of Sociology, 15(1), 381-404.

Luxton, M., \& Bezanson, K. (Eds.). (2006). Social reproduction: Feminist political economy challenges neoliberalism. McGill-Queen's Press-MQUP.

McDowall, D. (2003). Modern history of the Kurds. IB Tauris.

Mojab, S. (2003). Kurdish women in the zone of genocide and gendercide. Al-Raida, 21(103), 20-25.

Mortimer, C. (2018, February 4). "Barin Kobani: Video of Kurdish female fighter's body prompts outrage [The Independent]. Retrieved from https://www.independent.co.uk/news/world/middle-east/barin-kobani-kurdishfighter-video-female-fighter-body-mutilated-a8194261.html?fbclid=Iw AR3ngzBO5QyX2fIZpsw_bgZOU5wEfHPQYfoFovEGW91_9viPOPqz4YDiRq4

Öcalan, A. (2007). Prison writings: The roots of civilization (K. Happel, Trans.). London: Pluto Press.

Öcalan, A. (2011). Prison writings: The PKK and the Kurdish question in the 21st Century (K. Happel, Trans.). London: Transmedia.

Orhan, M. (2016). Political violence and Kurds in Turkey: Fragmentations, mobilizations, participations \& repertoires. Routledge. p. 112

Ostergaard-Nielsen, E. (2000). Trans-state loyalties and politics of Turks and Kurds in Western Europe. Sais Review, 20(1), 23-38.

Özcan, A. K. (2006). Turkey's Kurds: A theoretical analysis of the PKK and Abdullah Öcalan. Routledge.

Özsoy, H. (2010). Between gift and taboo: Death and the negotiation of national ldentity and sovereignty in the Kurdish conflict in Turkey. (Unpublished doctoral dissertation). University of Texas, Austin.

Picchio, A. (1992). Social reproduction: The political economy of the labour market. Cambridge University Press.

Raffles, H. (1999). Local theory: Nature and the making of an Amazonian place. Cultural Anthropology, 14(3), 323360.

Saraçoğlu, C. (2010). Kurds of modern Turkey: Migration, neoliberalism and exclusion in Turkish society. London: Tauris Academic Studies.

The 79-day Siege of Cizre, announced on the 14th of December, 2015, (2016, March 3-12). HDP Cizre Working Committee undertook [Report].

Üstündağ, N. (2016). Self-defense as a revolutionary practice in Rojava, or how to unmake the state. South Atlantic Quarterly, 115(1), 197-210.

Wahlbeck, Ö. (1998). Transnationalism and diasporas: The Kurdish example. University of Oxford: Transnational Communities Programme.

*All translations from Turkish and Kurdish are mine unless otherwise cited. 